\title{
THE ROLE OF SOME COOPERATIVE METHODS AND THEIR MODIFICATIONS IN DEVELOPING FOREIGN LANGUAGE COMMUNICATIVE SKILLS OF THE STUDENTS AT HIGHER EDUCATIONAL INSTITUTIONS
}

The article analyzes some cooperative methods that are used for the development of foreign language communicative skills of students at higher educational institutions. Some co-operative structures of Spencer Kagan and the Singaporean teaching methodology, the modification of Elliot Aronson's "Jigsaw" method Masami Yoshida's "Communication Jigsaw" method are presented. These methods and their modifications can be effectively used to develop the language and communicative skills of students at higher educational institutions, since the use of these methods creates maximum speaking opportunities for students with different levels of speaking skills. When learning to communicate in a small environment: in a pair or in a microgroup with a clear role distribution, students work with increased interest, motivation, and thus a willingness to engage fully within and outside the group. In addition, when working in a group, students feel more free and relaxed in expressing their thoughts, free themselves from the fear of making a lexical or grammatical mistake, focusing more on content than form, which contributes to the speed and fluency of their speech. Moreover, in the group students learn to hear and listen to one another, to explain and support their opinions, to find common ground and to resolve misunderstandings. Thus, a pair and group work, which is the basis of cooperative learning, forms not only a speaker, but a self-sufficient personality, increases self-esteem and a sense of dignity and pride for their achievements. The use of cooperative methods contributes to the development of students' scientific thinking, as it involves joint research, projects, writing reports and articles, participation in round tables, discussions and debates. Through these activities students learn to make their own discoveries in collaboration, which enhances the mutual respect and understanding of everyone's values. Thus, students become more ambitious and responsible, which certainly leads to a significant increase in their overall academic performance.

Key words: speaking, foreign language communication, cooperative learning, collaboration, group work.

Formulation of the problem. Nowadays, one of the most important tasks of higher education is the formation and development of foreign language skills of future professionals. The introduction of cooperative learning methods in the educational process helps to create the conditions for the effective formation and development of foreign language communication skills of students, taking into account the level of language proficiency and individual characteristics. Cooperative learning is an extremely effective educational strategy in the modern higher educational system, according to which new knowledge is acquired through joint research of several people on a particular issue. Knowledge and skills acquired through the creation of a research and productive atmosphere are easier to transfer to life situations, as communicative competence is one of the basic components of any type of professional activity.

The cooperative method is based on the principle of interaction or emphasis on learning to communicate through interaction in the language being studied.
Thus, the co-operative teacher's management activities should be aimed at creating the need for students' interaction. It is extremely useful to use the personal experience of students as an important component of classroom learning.

Cooperative teachers instruct students how to invite and apologize, to agree, and to disagree, making sure that they are able to use basic tenses or conditional sentences in particular. In this regard, role plays, communicative games, simulations, solving puzzles, interviewing, searching books in the library, writing poems or collecting stories are integral parts of cooperative learning and popular with all cooperative teachers.

The most significant benefits of cooperative learning are improving students' academic performance, developing the ability to think critically, non-stereotypically perceiving people, students' desire for collaboration and constructive socialization, personal growth, and positive student attitude toward teachers and the institution. 
These goals are achieved through the effective work of students in the group due to a number of factors:

- defining a common goal, special assignment or resources (for example, when a student has only some of the material required to complete the assignment);

- role assignment (leader, organizer, researcher, instructor, controller, expert, speaker, observer);

- summation of the points received by the members of the group during the evaluation;

- giving additional points to each participant in case of success of the whole team;

- appointment of the collective reward;

- increasing the time to think about the answer, which enables less well-prepared students to take an active part in the task [1, p. 14-15].

The purpose of the article is to analyze the possibilities of using the didactic potential of some cooperative methods of Spencer Kagan, Eliot Aronson, including their modifications, for the development of foreign language communicative skills of students at higher educational institutions.

State of research. Cooperative learning has its origins in the last century, based on the principles of Communicative Learning and Constructivist Theories. According to methodologists such as David Wilkins (1976) and David Nunen (1991), the basic principles of communicative learning are the following:

- focusing on the main communicative functions that people perform through language;

- emphasis on learning to communicate through interaction in the language being studied;

- attempting to combine classroom learning with out-of-class language activation;

- using students' personal experience as an important component of classroom learning [2, p. 69-70].

According to constructivist didactics embodied by such well-known methodologists as M. Montessori, R. Steiner, S. Fren, S. Amonashvili, knowledge is obtained through working together on certain tasks, in the course of which the exchange of thoughts, ideas and mutual assistance takes place.

Co-operative ideas are being developed by such famous scholars as Eliot Aronson and Spencer Kagan. Eliot Aronson created the cooperative method "Jigsaw". This method encouraged the development of a series of its modifications. Masami Yoshida from Chiba University, Japan, created "Communication jigsaw" in order to activate the research work of future scientists. Dr. Spencer Kagan, chairman of the Resource Institute for Teachers (USA), invented the cooperative method, which is a series of structures known as Kagan structures. These structures have been used in the Singaporean teaching methodology, which has become extremely efficient.
Results of the research. We should pay our attention to the most widely spread Kagan structures. The Round Robin structure assumes that students in pairs or groups, alternately, having the same amount of discussion time (approximately 30 seconds), answer a teacher's questions, or speak on a given topic, solving a problem suggested by the teacher. The structure includes the following steps: the teacher identifies a topic or problematic question that provides a wide range of possible answers; team members give verbal answers.

The Timed Pair Share structure is used to organize paired work, during which students are given the same amount of time to express their thoughts. The ThinkPair-Share structure includes three steps to complete a task: students perform the tasks individually; discuss the answer in pairs; share their thoughts with other couples or the whole group.

The Team-Pair-Solo structure involves performing the task first in a group, then in pairs, and at the last stage individually.

The Team Statement structure assumes that students come together in teams to formulate definitions together. Each team member gives their own definition of the term, then individual ideas are combined to form a common definition that broadens the meaning of the concept and shares their thoughts with other couples or the whole group.

The Three-Step-Interview structure is performed according to the following steps: one student asks the other, the other answers; roles change; groups of 4 people are formed in which students take turns telling what they have learned.

The One Stray structure assumes that one of the group members is transferred to another team to share information. The Rally Coach structure enables students working in pairs to perform an assistant function while the partner is completing tasks. Assistant students are given the keys to the assignment.

The Inside-outside circle structure allows students working in pairs to ask questions and get to know each other better. Therefore, the application of this structure greatly improves the skills of foreign language communication and is an effective tool in the development of new vocabulary, repetition of definitions of words, preparation for future exams and other tests, etc. Let's take a closer look at this structure. It is performed according to the following steps: the teacher or students prepare questions for discussion; students form pairs, with students from each pair forming a large circle of faces outside; other students become face to face with their partners; the students of the inner circle ask the students of the outer circle who answer them; partners change roles (this stage may be missing); students of the inner circle turn clockwise to the new partner; these steps can be repeated. 
According to the rules of the Talking Chips structure a student is given the opportunity to speak when his or her chip is on the desk. At the end of the answer the student removes his chip from the table and passes the baton to the next participant, who puts his chip on the table and begins to speak. According to the rules, students cannot interrupt each other.

The Spin-N-Review structure has the following sequence: students read questions, answer questions; verify the correctness of the answer, express approval or provide assistance.

In the Spin-N-Think structure students read and answer the questions, paraphrase, supplement, express approval, discuss.

The Rally Coach structure enables students working in pairs to perform an assistant function while the partner is completing tasks. Assistant students are given the keys to the assignment [3, p. 7-9].

Among the variety of Spencer Kagan structures, one of the most productive is the Showdown structure, which consists of the following steps: each team receives a set of question cards and puts them in the center of the table with questions down; the teacher selects one student from each group for the role of Showdown Captain; Showdown Captain takes the top card, reads questions and gives the team time for reflection; all team members, including Showdown Captain, write the answers, they work individually; upon completion, they inform Snowdown Captain of their readiness lifting the thumbs up and turning the answers face up; Showdown Captain gives a Showdown signal; team members discuss their answers, finding the right option; Showdown Captain manages the discussion process; if the answer is correct, the team celebrates the victory; in case of wrong answer, team members correct each other by analyzing mistakes; the next round is led by a team member to the left of Showdown Captain [3, p. 13].

Minor changes may be made to the structure. This allows the teacher to read the questions verbally to students or to use questions highlighted on the projector screen or recorded on the blackboard.

This structure contributes to the effective learning of the learning material, as students do not simply answer questions, they explain their opinion to other team members, thus effective mutual learning. In addition, the structure develops a range of social skills, such as expressing their opinions, interacting with other members of the team. At the same time, literacy of spoken and written language is increased, because the ability to communicate with other members of the team depends on the ability to write competently and logically.

The given structures can be effectively used in foreign language training to develop skills and abilities of foreign language communication. The positive advantages of these structures are the positive interaction of the participants. The teacher needs to change the classroom atmosphere, support students' attempts to take risks, find their own options, and not be afraid to make mistakes. With a favorable psychological climate, the student becomes aware of himself and his personal qualities as values, which is an important condition for the formation of self-esteem and desire for self-improvement. Cooperative learning motivates students, facilitating more intensive work than they used to do during a traditional lesson. Students become more active, make more effort, and so learning becomes more focused and effective. In addition, cooperative foreign language teaching methods can be harmoniously combined with traditional teaching methods and successfully used by higher education teachers to enhance the effectiveness of foreign language learning $[4$, p. 4].

Thus, the application of the cooperative Spencer Kagan model of learning not only improves the skills and abilities of foreign language communication, but also achieves significant positive transformations in the cognitive, emotional, motivational, value and activity areas of the individual.

Singapore education is worth studying as well. Singapore education system was created from scratch 50 years ago. Since then the country has achieved tremendous success. Nowadays Singapore is known to the world community as a country with higly developed economy. The roots of this prosperity lie in Singapore Curriculum Philosophy. The Singapore Teaching Practice shows the effectiveness of learning due to holistic education. Learning flourishes in caring and safe learning environments. Students acquire knowledge actively through the development of thinking skills and dispositions and assessment is used to improve the learner's acquisition [5].

In the Singaporean methodology an individual approach to each student is of paramount importance. A lesson contains various types of activities, so a student is never bored and feels comfortable. Teaching stimulates the development of cognitive activity of a student and develops creative thinking. Each lesson involves cooperation, mutual understanding, an atmosphere of joy and dedication.

The Singapore programme highlights the trends of the XXI century, develops critical thinking among students, problem-based learning, joint group learning, and the formation of innovative teaching teams. These components allow to teach students to think, express their opinions, and be constantly active.

Singaporean teaching methodology is not based on the traditional teaching where a teacher is a soure of information. This methodology is a set of theses ans formulas called structures, from which a lesson is built. 
There are structures for both academic purposes and for class and team building. Each structure has a rigid framework and its own name but one can put them in any order. There are about 250 structures. We will mention only some of them.

The Management Mat structure is a structure, according to which students are arranged in one team of four people: two sit next to each other and two are their opponents. Tables are shifted together, students sit at them facing each other, two of them turn sideways to the school board. So, they may act as partners in the face abd partners on the shoulder.

The Clock Buddies structure is a structure where the group performs a certain task for a specific time, because after the signal the composition of the team will change. This structure is used when checking homework.

The High Five structure is a signal of silence and attention, concentration on the teacher's raised palm. It is used at the beginning of the lesson: the teacher raises his hand and says, addressing the class, "High five", students must do the same, showing that they get ready for the next stage of work.

The Stir the Class structure is a structure where students are allowed to roam the class freely to collect maximum thoughts and answers on their list, then they carry out a general analysis and answer the posed question. The time is limited.

The Corners structure suggests the distribution of students in the corners of the class according to their choices. The group is formed taking into consideration students' interests and motivates students to work in a team.

The Mix Pair Share structure is a training structure in which participants move while they listen to the music and form a pair when the music stops, then discuss the proposed topic using the Rally Robin structure for short answers and the Timed Pair Share structure for detailed answers.

The Jot Thoughts structure is a training structure in which participants loudly pronounce a word on a given topic, write it on a piece of paper and put it face up in the centre of the table. Each participant must fill in four pieces, therefore, in the centre of the table will be sixteen pieces of paper. While speaking students should use them, thus expanding their vocabulary.

The Zoom in structure is a learning structure that helps to review reading material more thoroughly, stopping and answering questions to generate interest to a particular topic.

The Quiz-Quiz-Trade structure is a learning structure in which students test and train each other according to the material they have studied, using cards with questions and answers on the topic.

The Connect-Extend-Challenge structure is a learning structure that helps to deepen knowledge on the topic, linking with previous experience and thinking about possible difficulties [6, p. 101-110].
Using the main structures mentioned above, the entire class is involved in the studying process in the Singapore system. To organize the educational process the teacher applies mental techniques and learning structures developed by American professor Spencer Kagan. The variety of patterns promotes the creativity of a teacher and motivates the students for prolific activities.

To enhance the studying process a glance should be given to the modification of Eliot Aronson's "Jigsaw" cooperative learning method. The "Communication Jigsaw" strategy was invented in 2018 by Masami Yoshida from Chiba University, Japan. The purpose of this modification is to promote communication of university students as future scholars. Writing sheets (time-independent written documents) are used as resources for reports and discussions and allow students to get acquainted with all the subtopics. So the "Communication Jigsaw" strategy enhances the process of acquiring and analyzing information [7, p. 214].

Anderson stated that the Japanese students rarely initiated discussion, avoided bringing up new topics, didn't challenge the instructor, seldom asked questions for clarification, and didn't volunteer answers [8, p. 104]. The majority of the students from different countries are not confident enough in their knowledge tend not to be very active and are reluctant to speak up.

The "Communication Jigsaw" method can help students overcome their shyness. Student's result of investigation is recorded in a report sheet. Then discussions take place in expert groups, similar sheets are presented. Students are invited to share their ideas, classify and assess them. This method encourages less ta lkative students to participate in discussions. The "Communication Jigsaw" strategy stipulates that all the students have to explain the reports of other students. Then, in the original group, they listen to a report, read a description carefully, and ask questions. Thus, they become aware of the content. In addition, peer review evaluation within the expert groups is expected.

Unlike other "Jigsaw" strategies the "Communication Jigsaw" approach allows the access to two subtopics: a report sheet subtopic and an expert group subtopic. Moreover, students may write comments regarding each report sheet from other subtopics. The student can select on one's own a target report sheet.

Thus, free communication in the original and expert groups occurs. The emerging communication may be both co-presence communication and communication through written documents.

The effects of the "Communication Jigsaw" are the following:

- The "Communication Jigsaw" supports the formation of a scholarly community of students while communicating within comment session environment. 
- The objective of the comment session is not to get skills and knowledge but comprehension of the whole process.

- The students' motivation is increased that leads to self-directed learning.

The benefit of such learning includes searching and assessing unknown information in cyberspace. The "Communication Jigsaw" technique has been frequently used in contemporary lesson planning and represents a comprehensive method that combines motivation, interaction, and deep learning.

Thus, we can state on the effectiveness of this modification of the "Jigsaw" method in developing foreign language communicative skills and creative thinking, necessary for preparation of projects, theses and presentations.

Conclusions and prospects of further research. All in all, the cooperative learning methods and their modifications discussed in the article can be effectively used for developing foreign language communicative skills of the students at higher educational institutions. A great advantage of these methods is the positive interaction of the participants. The teacher needs to change the classroom atmosphere, support students' attempts to take risks, find their own options, and not be afraid to make mistakes. In a favorable psychological climate, the student becomes aware of oneself and one's personal qualities as a value, which is an important condition for the formation of self-esteem, selfrespect and desire for self-improvement. Cooperative learning captures students, facilitating intensive work than they are used to doing during a traditional lesson. Students become more active, make more effort, and thus, the learning becomes more focused and effective.

\section{References:}

1. Cooperative learning in foreign language teaching. URL: https://skemman.is/bitstream/1946/17630.

2. Harmer J. The practice of English Language Teaching. London : Pearson Longman, 1991. 448 p.

3. Cooperative learning: quick reference guide of Kagan Structures. URL: https:// sirblois.files.wordpress.com/2016/09/cooperative-learning-activities.pdf.

4. Kagan S., High J. Kagan Structures for English Language Learners. ESL Magazine. 2002. № 5 (4). P. 4.

5. The Singapore Teaching Practice. URL: https:// www.moe.gov.sg/about/singapore-teaching-practice.

6. White D., Braddy A. Ready-to-Go instructional strategies that build collaboration, communication, and critical thinking. Corwin Press, 2017. 160 p.

7. Masami Yoshida. Communication Jigsaw: A Teaching Method that Promotes Scholarly Communication. P. 208-221. URL: https:// online-journals.org/index.php/i-jet/article/ view/8850/5238.

8. Anderson F.E. The enigma of the college classroom. A handbook for teaching English at Japanese colleges and universities. 1993. P. 101-110.

Головко О., Драч О. Роль окремих кооперативних методів навчання та їх модифікацій у розвитку умінь і навичок іншомовної комунікації студентів вищих навчальних закладів

У статті проаналізовані окремі кооперативні методи, які застосовуються для розвитку умінь і навичок іншомовної комунікації студентів вищих навчальних закладів. Представлено окремі кооперативні структури Спенсера Кагана та створену на їх базі Сінгапурську методику навчання, модифрікацію методу “Пилка" Еліота Аронсона, метод "Комунікативна пилка" Масами Йошида. Ці методи та їхні модифрікації можуть бути ефрективно використані для розвитку умінь і навичок іншомовної комунікації студентів вищих навчальних закладів, оскільки їх застосування створює максимальні можливості говоріння для студентів із різним рівнем мовленнєвих навичок. Завдяки спілкуванню у невеликому оточенні - у парі або у мікрогрупі з чітким розподілом ролей - у студентів підвищується зацікавленість, вмотивованість, а отже, готовність до всебічної колаборації як усередині групи, так і поза їі межами. Крім того, працюючи у групі, студенти відчувають більшу свободу та розкутість у висловлюванні своїх думок, звільняються від страху зробити лексичну або граматичну помилку, фоокусуючись більше на змісті, ніж на фоормі, що сприяє підвищенню швидкості та плавності їх мовлення. Більш того, у групі студенти вчаться чути та слухати один одного, пояснювати та відстоювати свою думку, знаходити спільну мову та залагоджувати непорозуміння. Таким чином, парна та групова робота, покладена в основу кооперативного навчання, формує не лише мовця, а й самодостатню особистість, підвищує самооцінку та почуття власної гідності та гордості за свої досягнення. Застосування кооперативних методів сприяє розвитку наукового мислення студентів, оскільки передбачає спільні дослідження, проекти, написання доповідей і статей, участь у круглих столах, дискусіях і дебатах. Завдяки таким видам діяльності студенти навчаються робити власні відкриття у співпраці, що підвищує взаємоповагу та розуміння цінності кожного. Отже, студенти стають більш амбітними та відповідальними, що безумовно, веде до значного підвищення їхніх загальних академічних результатів.

Ключові слова: говоріння, іншомовна комунікація, кооперативне навчання, колаборація, групова poбота. 